\title{
THE IMPLEMENTATION AND APPLICATION OF THE CHARTER OF FUNDAMENTAL RIGHTS OF THE EU IN AUSTRIA
}

\author{
MARCUS KLAMERT
}

\begin{abstract}
:
This contribution will briefly lay out the sources of the protection of fundamental rights in Austria, with the Charter of Fundamental Rights being the most recent addition. The primary law status of the Charter under EU law has created frictions in the established division of competences between the highest courts in Austria. With the so-called Charter judgement, the Constitutional Court has reversed its settled case law on not applying EU law as a standard of review and grounds for repeal except in manifest cases, which has led both the Administrative Court and the Supreme Court to 'push back' to preserve their competence to recognise directly applicable Union law. In the legislative process, as this contribution also shows, the Charter seems yet not to have received the same level of attention as other sources of fundamental rights.
\end{abstract}

Key words: Charter of Fundamental Rights of the EU; human rights; Constitutional Court; judicial review; Convention for the Protection of Human Rights and Fundamental Freedoms; legislative process; directly applicable EU law; preliminary reference

Klíčová slova: Listina základních práv EU; lidská práva; Ústavní soud; soudní přezkum; Úmluva o ochraně lidských práv a základních svobod; legislativní proces; přímo použitelné právo EU; řízení o předběžných otázkách

DOI: $10.14712 / 23366478.2018 .36$

\section{INTRODUCTION}

In this contribution, I would like to discuss some aspects related to the fundamental rights architecture in Austria, specifically concerning the implementation of the Charter of Fundamental Rights of the EU (ChFR, Charter). I will start by laying out the three instruments that form the traditional foundations of fundamental rights protection in Austria, the Convention for the Protection of Human Rights and Fundamental Freedoms (Convention), the Staatsgrundgesetz (StGG), and the Bundesverfassungsgesetz (B-VG), including other sources that rank as constitutional law (see Article 149 B-VG). I will continue by setting out the delimitation of the jurisdiction of the three Austrian Apex Courts, viz. the Verfassungsgerichtshof (Constitutional Court, VfGH), the Verwaltungsgerichtshof (Administrative Court, VwGH), and the Oberste Gerichts- 
hof (Supreme Court, OGH). This will be followed by a discussion of the jurisdiction of the VfGH on fundamental rights and EU law, and, subsequently and specifically, of its famous "Charter judgement" and the 'responses' by the VwGH and OGH. Finally, I will briefly explain the Austrian legislative process and the role of the Constitutional Service in it, highlighting the way the Charter has been used to ex ante review the legality of Austrian laws and regulations.

\section{THE FOUNDATIONS OF THE FUNDAMENTAL RIGHTS ARCHITECTURE IN AUSTRIA}

The oldest part of the fundamental rights sources in Austria still in force are the so-called Fundamental Law concerning the general rights of citizens (Staatsgrundgesetz 1867, StGG) passed on 21 December 1867 during the Austro-Hungarian Empire. The StGG, also known as the "December Constitution", laid down the fundamental rights and the right of personal liberty of citizens of the Austrian part of the Empire. With amendments such as on the freedom of art and data protection, it is still in force today, and comprises fundamental freedoms such as equality before the law, the freedom of belief and conscience, and the freedom of science and teaching that are partly overlapping with other sources (see below). The StGG was incorporated into the constitutional legal order of the new democratic Republic of Austria in 1920. Especially, Article $6 \mathrm{StGG}$ provides for the right to engage in a gainful occupation and the freedom of real property transfer for Austrian nationals, Article $18 \mathrm{StGG}$ for the right to the freedom of choice of occupation and vocational training, and Article $12 \mathrm{StGG}$ for the right to the freedom of association and assembly.

The Federal Constitutional Law (Bundesverfassungsgesetz, B-VG) of Austria of 1920, in particular, provides for the equality of all citizens before the law (Article 7 $\mathrm{B}-\mathrm{VG}$ ), and the right to a fair trial before a lawful judge (Article 83(2) B-VG). Articles 26, 60, 95, and $117 \mathrm{~B}-\mathrm{VG}$ confer on Austrian nationals the right to vote and to stand as a candidate for election. The right to data protection is also enshrined in Section 1 of the Data Protection Act.

Articles 62-69 of the Treaty of Saint-German-en-Laye of 1919 guarantee constitutional rights of minorities including the right to equal treatment and the prohibition of discrimination. Article 7 of the Austrian State Treaty of 1955 provides rights for the Slovenian and Croatian minorities relating, among other, to the use of minority languages in contacts with public authorities and in the fields of education and cultural life (see also Article 8 B-VG). Article I of the Federal Constitutional Law Implementing the International Convention on the Elimination of all Forms of Racial Discrimination provides for the right to equal treatment of non-nationals relative to one another.

After becoming a member of the Council of Europe, Austria signed the Convention for the Protection of Human Rights and Fundamental Freedoms on 13 December 1957 and ratified it - together with its first Additional Protocol of 1952 - on 3 September 1958. The Convention is formally fully equivalent to the original catalogue of fundamental rights in the B-VG and the StGG, and is thus directly applicable federal consti- 
tutional law. The VfGH has displayed an almost unreserved willingness to follow the interpretations of the Convention first by the Human Rights Commission and now by the European Court of Human Rights (ECtHR) and, where necessary, even to adapt its case law accordingly.

There are overlaps between the fundamental rights foreseen in the B-VG and especially the StGG on the one hand, and the Convention on the other hand: the right to life is enshrined in Article $85 \mathrm{~B}-\mathrm{VG}$, Article 2 Convention, and Protocol 6 to the Convention; the right to equality of all citizens before the law is provided by Article $7 \mathrm{~B}-\mathrm{VG}$ as well as by Article $2 \mathrm{StGG}$; the prohibition of slavery and forced labour is provided by Article 4 Convention and Article $7 \mathrm{StGG}$; the freedom of movement of persons and property by Article 4(1) StGG and Article 2(1) of Protocol 4 to the Convention; the freedom to choose a place of residence by Article 6(1) StGG and Article 2(1) of Protocol 4 to the Convention; the inviolability of domiciliary rights by Article 9 StGG, the Act on the Protection of Domiciliary Rights, and Article 8 Convention; the protection of the secrecy of correspondence and telecommunication by Articles 10 and 10a StGG and Article 8 Convention; the right to the inviolability of property by Article 5 StGG and Article 1 of Protocol 1 to the Convention; the right to the freedom of expression of opinion by Article $13 \mathrm{StGG}$ and Article 10 Convention; the right to freedom of conscience and religion, including the freedom to practice one's religion by Articles 14 and $16 \mathrm{StGG}$ as well as by Article 9 Convention; and the right to liberty is provided by the Federal Constitutional Law on Personal Liberty as well as by Article 5 Convention.

Thus, the Austrian legal order has been accustomed to having different and partly overlapping sources of fundamental rights, even before the advent of the Charter. ${ }^{1}$

\section{THE AUSTRIAN APEX COURTS}

Traditionally, the three supreme judicial bodies VfGH, VwGH, and OGH have been characterized as equally ranking peer courts ("Highest Courts", Höchstgerichte), with different functions and a corresponding division of labour. ${ }^{2}$

The primary task of the VfGH is to examine conformity with Austrian constitutional law, which also includes the protection of constitutionally guaranteed (fundamental) rights. It is, in particular, called upon to review the constitutionality of Federal and Provincial laws and to declare their unconstitutionality, to review the lawfulness of ordinances by administrative bodies, and to examine the constitutionality of highest-instance decisions by administrative bodies, leading to the repeal of the latter, mainly on the grounds of an arbitrary execution of laws. Moreover, elections can also be contested before the VfGH. The competence of the VfGH for the control of certain acts of the

1 See, further, GRABENWARTER, Ch.: Grundrechte in Österreich, § 2 Verfassungsrecht, Völkerrecht und Unionsrecht als Grundrechtsquelle. In MERTEN, D. - PAPIER, H. J.: Handbuch der Grundrechte - in Deutschland und Europa, C. F. Müller, 2014, p. 51, especially p. 66 et seq.

2 See ORATOR, A.: The Decision of the Austrian Verfassungsgerichtshof on the EU Charter of Fundamental Rights: An Instrument of Leverage or Rearguard Action? German Law Journal, 2015, No. 6, p. 1429, p. 1431. 
administration enshrined in Article $144 \mathrm{~B}-\mathrm{VG}$ dates back to 1867 and is considered the central pillar of the protection of citizen rights. ${ }^{3}$

The VwGH as the 'highest court' is called upon to review the lawfulness of last-instance decisions by administrative bodies, with the exception of ordinances, which only the VfGH may examine and repeal, and with the exception of administrative acts that come under the competence of the VfGH as explained above. This, however, makes the VwGH competent for the bulk of complaints against the administration in Austria. EU law as a standard of review would generally also fall within the VwGH's realm of competence, as explained below.

The OGH is the highest instance in civil and criminal law cases. Until 2015, as a matter of principle, parliamentary statutes on civil and criminal matters would not be reviewable by the VfGH unless they were referred to it by the OGH. Since 2015, this division of labour has been modified with the introduction of a right for individuals to raise the constitutionality of regulations and statutes applicable in civil and criminal proceedings before the VfGH. It is also noteworthy that judgments by the OGH or the $\mathrm{VwGH}$ cannot by appealed to the VfGH on the grounds that they violate a constitutionally guaranteed right. ${ }^{4}$

\section{JUDICIAL REVIEW IN LIGHT OF EU LAW BEFORE THE CHARTER JUDGEMENT}

The VfGH has acknowledged and accepted the supremacy of Union law and has thus followed the Court of Justice of the EU (CJEU). ${ }^{5}$ In addition, it was one of the first Member State constitutional courts that made a preliminary reference to the CJEU in $1999 .{ }^{6}$ At the same time, the VfGH, starting in the late 90 s, largely passed the responsibility for judicial review in the light of Union law on to the VwGH. ${ }^{7}$

The VfGH has held that a violation of EU law would not constitute a breach of the Constitution and would therefore not be of concern to it, but it would be tantamount to a violation of a simple (i.e. non-constitutional) domestic law, which would be for the VwGH to address. ${ }^{8}$ The VfGH only assessed the compatibility of a national law with EU law if national law manifestly contradicted Union law, making the question of compatibility so obvious that there could be no room for reasonable doubt. ${ }^{9}$

3 BEZEMEK, Ch.: A Kelsenian model of constitutional adjudication. The Austrian Constitutional Court. Zeitschrift für öffentliches Recht, 2012, No. 1, p. 115.

4 See MÜLlER, A. Th.: An Austrian "Ménage à Trois". The Convention, the Charter and the Constitution. In ZIEGLER, K. - WICKS, E. - HODSON, H.: The UK and European Human Rights: A Strained Relationship? Hart Publishing, 2015, p. 299, p. 318.

5 See, e.g., VfSlg. (Collection of judgements by the VfGH) No. 14.805/1997; 14.951/1997; 15.036/1997; $15.215 / 1998 ; 15.450 / 1999 ; 16.050 / 2000 ; 16.100 / 2001$. Supremacy is also accepted in relation to Austrian constitutional law. This openness stands in contrast to some other national constitutional courts in the EU.

6 See VfSlg. 15.450/1999 on the Austrian law for an energy tax refund. See also VfSlg 16.050/2000, $16.100 / 2001$.

7 See, for details on the many intricacies of this case law, ÖHLINGER, T. - POTACS, M.: EU-Recht und staatliches Recht. LexisNexis, 2017, p. 180 et seq.

8 VfSlg. 14.886/1997; 15.583/1999.

9 VfSlg. 14.886/1997; 19.628/2012. 
Fundamentally, a contradiction between an Austrian law of general application and Union law would (only) lead to the non-applicability of the former, which all state organs must acknowledge incidentally, but it would not lead to its repeal. ${ }^{10}$ In case of a complaint by an individual because of an alleged violation of constitutionally guaranteed rights, directly applicable EU law would render the complaint inadmissible a limine, because, as reasoned by the $\mathrm{VfGH}$, there could be no infringement of a provision guaranteed by constitutional law if national law is set aside by directly applicable Union law. ${ }^{11}$

In cases where EU law is not directly applicable, such as with certain directives, the VfGH has held that the annulment of the national implementing law is inadmissible where Union law does not give the national legislature any latitude for national design, so that the legislature would have no possibility of creating a substitute provision which would comply with both Union and national constitutional law. ${ }^{12}$

All this would have meant that the directly and broadly applicable Charter would have to be observed in civil and administrative cases before the VwGH and the OGH. It would not, in contrast, constitute a benchmark before the VfGH, and complaints by individuals before the VfGH relying on directly applicable Charter rights would even have been inadmissible.

\section{THE “CHARTER JUDGEMENT” BY THE VFGH}

The Charter judgement by the VfGH of 2012 concerned two applications for international protection by Chinese nationals. ${ }^{13}$ One claimed to have hurt a police officer in China so that she would not have the possibility to return to China, the other that he had incurred large debts in China. The Austrian Federal Asylum Office (Bundesasylamt) dismissed both motions in the first instance and the Asylum Court dismissed the subsequent appeals without oral hearing. The VfGH also dismissed both complaints, which were based only on Article 47(2) of the Charter. ${ }^{14}$

It was therefore in an obiter dictum that the VfGH upended its treatment of EU law laid down in settled case law as explained above. The VfGH found that because of the EU law principle of equivalence, "comparable" Charter rights, thus rights guaranteed by the Charter that are "similar in wording and purpose" to Austrian constitutionally guaranteed rights (including the Convention as explained above), could be invoked as constitutional rights before the $\mathrm{VfGH}$, and that they, within the scope of application of the Charter, would constitute a standard of review for constitutional complaints. The VfGH thus granted the Charter constitutional status, allowing it to be used as a legal benchmark. Clearly, this did not make the Charter formally a part of constitutional law

\footnotetext{
0 VfSlg. 15.189/1998.

1 VfSlg. 19.632/2012.

12 VfSlg. 18.642/2008; G 52/2016 of 12 October 2017 (national law implementing the Consumer Protection Directive).

$13 \mathrm{U} 466 / 11$ and $\mathrm{U}$ 1836/11.

14 VfSlg. 19.632/2012.
} 
as it has been done with regard to the Convention, which was 'lifted' into the rank of constitutional law by ratification. ${ }^{15}$

Charter rights can therefore be invoked before the VfGH as if they were constitutionally guaranteed rights, potentially leading to a declaration of unconstitutionality with regard to a national (federal) law. One limitation compared to constitutionally guaranteed rights is that the Charter only applies within its scope of application, which however is fairly wide. ${ }^{16}$ At the same time, if the VfGH declares a national law as being unconstitutional based on the Charter, this has implications for all cases to which the respective national law applies, which raises the issue of "reverse" discrimination. ${ }^{17}$ Another limitation is that the VfGH rectifies national law pro futuro only.

Relying on the principle of equivalence met with forceful criticism, and this argument was later qualified by the VfGH in that the finding by the VfGH would not in itself be required by this principle but would follow from it. ${ }^{18}$ Under the principle of equivalence, EU law does not require national procedures for enforcing rights derived from EU law to be identical to procedures for enforcing rights derived from national law. It is also not required that the most favourable available national procedure is applied to Union rights. According to the CJEU judgement in Pontin, it is decisive "whether actions concerned are similar as regards their purpose, cause of action, and essential characteristics". ${ }^{19}$ This requirement would however also have been fulfilled by leaving the Charter (as a part of Union law) within the competence of the VwGH (and the OGH) as is the case with all other parts of Union law as explained above.

The rationale behind the Charter judgement is that barring the VfGH from deciding on rights in the Charter that are identical to constitutionally guaranteed rights would not be in line with the system of centralised constitutional judicial review under the Austrian constitution. While this is true for many of the Charter "rights", ${ }^{20}$ many Charter provisions are "mere" "principles" (such as Article 22 or Article 37 of the Charter) and have a rather different normative structure. The VfGH therefore needs to assess which Charter provisions fall under the system laid out above in each individual case, and, in case of doubt, request a preliminary ruling by the Court of Justice of the EU. However, the VfGH also held that if the legislature, in exercising its latitude in implementing EU law, creates rules which, in addition to a fundamental right of the Charter, also affect a (different) constitutionally guaranteed right, the VfGH decides on the basis of that law if it has the same scope as the law of the GRC and if the limits for permissible interventions by the legislature in the constitutionally guaranteed rights are narrower or at least not wider than in the corresponding rights of the GRC. ${ }^{21}$ In such case, when applying the national law, there is no need to refer to the CJEU in the view of the VfGH.

15 See MÜLLER, op cit., p. 304.

16 See LOCK, T. Article 52 ChFR. In KELLERBAUER, M. - KLAMERT, M. - TOMKIN, J.: The EU Treaties and the Charter of Fundamental Rights - A Commentary, 2019 (forthcoming).

17 See HOLOUBEK, M. - LECHNER, E. - OSWALD, M.: Art 51 GRC. In HOLOUBEK, M. - LIENBACHER, G.: GRC-Kommentar, MANZ Verlag Wien, 2014, para. 60.

18 VfGH B 166/2013-17, 12 March 2014, VfSlg. 19.865/2014, para. 3.2.2.1.

19 Case C-63/08 Pontin, ECLI:EU:C:2009:666, para. 45.

20 Article 7 (private and family life), Article 8 (data protection), Article 11, Article 15, Article 16, Article 21(1) (non-discrimination) ChFR. See ORATOR, op cit., p. 1438.

21 VfSlg. 19.632/2012, para. 44; VfSlg 19.892/2014, Pt. 2.2.8. 
This, as a matter of principle, creates two different levels of EU law for the purposes of judicial control by the VfGH. On the 'higher' level are the Charter rights as far as they are comparable to national rights, on another level is all other Union law not having this status before the VfGH. The latter, notably, also includes those fundamental rights of Union law that are derived from the common constitutional traditions of the Member states and international obligations for the protection of human rights to which member states were parties or acceded. ${ }^{22}$ This discrepancy was rationalised by the VfGH by arguing that "[T]he applicability of a detailed catalogue of rights and duties as set out in the [ChFR] is not comparable to the derivation of legal positions from general legal principles". However, under EU law, there is no difference in legal status between the written Charter rights and the fundamental rights in the form of unwritten general principles. ${ }^{23}$

It seems that the VfGH was concerned that, without the twist of the Charter judgement, it "would abdicate in favour of VwGH and civil courts and would utterly surrender the constitutional function of being the guardian of fundamental rights" as it has been put by one of the judges at the VfGH. ${ }^{24}$ At the same time, the Charter judgement was welcome by the CJEU as it raises the visibility of the Charter in Austria and could establish the VfGH as a privileged partner for a constitutional dialogue on fundamental rights in the EU. ${ }^{25}$

\section{SUBSEQUENT VFGH JUDGEMENTS}

In 2014, the VfGH examined the constitutionality of the national data retention laws implementing the Data Retention Directive 2006/24/EC. ${ }^{26}$ The court stressed once more that within the scope of EU law the Charter rights form benchmarks when checking the legality of national norms. The supremacy of EU law can in this context provide for efficient and directly applicable rights for individuals. It found that if the legislature makes use of its discretion when implementing Union law and creates regulations which affect besides a Charter right another constitutionally guaranteed right, then the Constitutional Court decides on the basis of this right whether it has the same scope of application as the right in the Charter and "if the limits for permissible legislative interference with the constitutionally guaranteed rights are narrower or at least not wider than the corresponding rights of the Charter of Fundamental Rights". This, it was found, could be assumed for the relation between Articles 7 and $8 \mathrm{ChFR}$ and the two constitutionally guaranteed rights of Article 8 Convention and Section 1 Data

\footnotetext{
2 See Article 6(2) TEU.

3 See also MÜLLER, op cit., p. 308 et seq.

24 See ORATOR, op cit., p. 1443, quoting VfGH judge Müller.

25 See HOLOUBEK, M.: Das Verhältnis zwischen europäischer Gerichtsbarkeit und Verfassungsgerichtshof. In GRABENWARTER, Ch. - VRANES, E.: Kooperation der Gerichte im Europäischen Verfassungsverbund-Grundfragen und neueste Entwicklungen, 12. Österreichischer Europarechtstag 2012, Dike Verlag, 2013, p. 157 , p. 166.

26 VfSlg. 19.702/2012.
} 
Protection Law 2000. This constituted the first declaration of unconstitutionality of an Austrian law by the VfGH based on the Charter.

In another case following the Charter judgement, two male Dutch citizens that had been married under Dutch civil law since 2002 attempted to renew their marriage in Tyrol where they had been living for several years. ${ }^{27}$ The Governor of Tyrol, acting as registry office of last instance, rejected their motion, since according to Austrian civil law at that time marriage was reserved to heterosexual relationships. ${ }^{28}$ The couple submitted a complaint, claiming that they were discriminated against on grounds of their sex and their sexual orientation based on the non-discrimination clause of Article 21 of the Charter, among other grounds. ${ }^{29}$ The VfGH recalled that the rights guaranteed by the Charter may be invoked as constitutionally guaranteed rights, provided that the guarantee enshrined in the Charter is similar in its wording and purpose to rights that are guaranteed by the Austrian Federal Constitution, as would be the case with Article $21 \mathrm{ChFR}$. The complaint however was rejected by the VfGH with the argument that the national non-discrimination law in question would not fall within the scope of application of the Charter because it would not aim to implement Union law. ${ }^{30}$ As, moreover, the national provisions were deemed outside the scope of application of the EU equality directives, there would be no provision of Union law specific to this area or that might influence it.

In some cases, the VfGH dealt with Article 47 of the Charter (this time in substance in contrast to the Charter judgement). ${ }^{31}$ Article 47 of the Charter also applies to administrative proceedings and thus has a wider scope of application compared to Article 6 Convention. ${ }^{32}$ At the same time, Article 47 of the Charter must be interpreted in the light of the ECtHR's case law on Article 6 Convention. ${ }^{33}$ The VfGH found Section 11(4) of the Federal Asylum Act (which however was no longer in effect at the time the judgement was handed down) to be unconstitutional because it had generally prevented certain senates of the (then still existing) Asylum Court from holding a public hearing of its own motion. ${ }^{34}$ In a case concerning a Somali citizen who applied for international protection, the Federal Office for Immigration and Asylum denied the appellant asylum, and the Federal Administrative Court rejected the complaint without conducting a public hearing. This was equally deemed a violation of Article 47 of the Charter. ${ }^{35}$ In another case concerning a decision to return a migrant to his country of origin, the VfGH for the first time recognised the direct applicability of Article 47(3) of the Charter, which

27 The VfGH added that, even if the Charter were applicable, the Austrian law would not be in violation of Article $21 \mathrm{ChFR}$ because of the wide margin of appreciation granted to the Contracting States relating to the issue of same-sex marriage.

28 Same-sex couples could only enter into a so-called registered partnership (eingetragene Partnerschaft) under the Registered Partnership Act of 2009 (Eingetragene Partnerschaften-Gesetz). But see now VfGH, 5 December 2017, G 258/2017 et a, repealing legal provisions which distinguish between opposite-sex and same-sex couples as of the end of 31 December 2018.

29 Also based on Article 7 B-VG and Article 14 read in conjunction with Article 8 Convention.

30 VfSlg. 19.865/2014.

31 See also GRABENWARTER, op cit., p. 73 et seq.

32 See the Explanations to Article 47 of the Charter.

33 See Article 51 of the Charter.

34 VfSlg. 19.845/2014.

35 VfSlg. 20.064/2016. 
stipulates that legal aid "shall be made available to those who lack sufficient resources in so far as such aid is necessary to ensure effective access to justice".

Albeit, according to Article 133(5) B-VG, legal matters pertaining to the competence of the VfGH are by law excluded from the competence of the VwGH, it could not monopolize the application of the Charter as a standard of judicial review as the following cases by the VwGH illustrate.

\section{THE “SPORTS CAR” JUDGEMENT BY THE VWGH AND OTHER JUDGEMENTS FOLLOWING THE CHARTER JUDGEMENT}

A case decided by the VwGH in 2013 concerned a seemingly innocuous dispute over a hearing before the Independent Finance Senate (UFS) about the deduction of input tax for a convertible sports car. ${ }^{36}$ The complainant had not been correctly summoned for the requested hearing. Such procedural errors had in the past only led to annulments of decisions of the UFS by the VwGH if the complainant could have proven that the holding of the hearing would have led to a different outcome, which would most likely have been impossible.

In this case, however, the VwGH relied directly on the Charter, arguing that "EU law requires each court of an EU Member State, including the Administrative Court, to fully safeguard the fundamental rights of the EU, in particular the fundamental rights of the Charter of Fundamental Rights". Article 47(2) of the Charter would grant the complainant the right to an oral appeal hearing and participation in the appeal hearing as a matter of EU law.

In other cases, the VwGH ruled that it may be necessary in certain cases to grant legal aid in the administrative proceedings before the Administrative Court directly on the basis of Article 47(3) of the Charter. ${ }^{37}$

\section{TWO REFERENCES BY THE OGH}

The OGH, more clearly than the VwGH, expressed its dissatisfaction with the Charter judgement and especially the reasoning put forward by the VfGH in a preliminary reference to the CJEU. ${ }^{38}$ The OGH wanted to know (in its first question), whether in the case of rules of procedural law under which the ordinary courts called upon to decide on the substance of cases are also required to examine whether legislation is unconstitutional but are not empowered to strike down legislation generally, this being reserved for a specially organised constitutional court, does the "principle of equivalence" in the implementation of [EU] law mean that, where legislation infringes Article 47 of the [Charter], the ordinary courts are also required, in the course of the pro-

\footnotetext{
6 VwGH 2010/15/0196. See also 2015/15/0041.

37 VwGH 2016/21/0152; 2015/21/0032.

38 Order of 17 December 2012, 9 Ob 15/12i.
} 
ceedings, to request the constitutional court to strike down the legislation generally, and cannot simply refrain from applying that legislation in the particular case concerned?

The OGH suggested that the principle of equivalence would not require this "given that it would prolong the proceedings and increase costs". ${ }^{39}$ The OGH also opined that "the fact that a right under the Austrian Constitution has the same scope as a right under the Charter does not trigger a waiver of the obligation to make a reference for a preliminary ruling". 40

This thinly veiled rebuke of the argumentation by the VfGH and the bait thus offered to the CJEU was not taken up by the latter. The CJEU did not 'take sides' in this Austrian 'game of thrones' and largely referred to its Melki and Abdeli case law. ${ }^{41}$

In another reference to the CJEU, the OGH again indirectly questioned the 'equivalence' reasoning of the VfGH. Section 363a(1) of the Austrian Criminal Procedure Act (StPO) mandates the renewal of a criminal trial if a judgement by the ECtHR finds a violation of the Convention by a criminal court that could have affected the outcome of the trial. ${ }^{42}$ The OGH asked whether it could not be argued that under this provision there should not be a difference between a renewal based on a judgement by the ECtHR and a judgement by the CJEU. This argument was rejected by the CJEU. It noted, among others, that it is a matter for national law (and not for EU law) whether to allow the renewal of a court proceeding where a final judgement has already been rendered. ${ }^{43}$

\section{THE CHARTER IN THE AUSTRIAN LEGISLATIVE PROCESS}

Since 2018, the Constitutional Service is part of the Federal Ministry of Constitution, Reform, Deregulation, and Justice. For 100 years before this time, it had been a division of the Federal Chancellery. The Constitutional Service is, among others, in charge of the Federal Ministries Act, acts as a legal expert, and reviews Federal laws and laws of the Provinces both in substantive and formal terms before they enter into force. It is primus inter pares when reviewing laws, thus its opinions are authoritative, but it has no veto right in the legislative process, different e.g. from the Legal Service of the Commission.

Thus, in theory, all bills and drafts for regulations are reviewed by the Constitutional Service with regard to their compatibility especially with Austrian constitutional law, including fundamental rights. Surprisingly, however, issues with regard to the Charter have been raised only in few cases in the last years. Mainly, in several instances, Article 8 of the Charter was invoked with regard to concerns about data protection standards. ${ }^{44}$

One possible explanation for this paucity of cases raising the Charter when reviewing laws and regulations for their conformity with constitutional law is that, as men-

39 Ibid, para. 25.

40 Ibid.

41 Joined Cases C-188/10 \& C-189/10, ECLI:EU:C:2010:363. See also ÖHLINGER - POTACS, op. cit., p. 186.

42 Case C-234/17 XC and Others (pending).

43 Case C-234/04 Kapferer, ECLI:EU:C:2006:178.

44 See eg https://www.parlament.gv.at/PAKT/VHG/XXIV/SNME/SNME_10489/index.shtml. 
tioned, from a formal perspective the Charter does not have the status of constitutional law. Technically, therefore, it is qualified as a ('mere') Union law and assessing the conformity with Union law has always been the sole responsibility of the competent Ministries, as is also always stated explicitly in a disclaimer at the beginning of reviews by the Constitutional Service.

\section{CONCLUSION}

This closes the circle on our discussion above on the 'hybrid' legal nature of the Charter, both in terms of the legal quality of the provisions it enshrines (rights and principles), as well as in terms of its equivalence under EU law with the rest of primary law, while 'only' constituting 'non-formal' constitutional law in Austria. The introduction of a written fundamental rights charter in EU law, in any case, has put the established division of competences between the Austrian apex courts to a test. While the Charter judgement has raised the visibility of the Charter in Austria, the awarenessbuilding as regards its impact on the legislature in Austria might still be a work in progress.

Priv. Doz. Dr. Marcus Klamert

Federal Chancellery of the Republic of Austria;

Vienna University of Economics and Business

marcus.klamert@wu.ac.at 